plant, "and few plants of any kind; no gentians, primroses, anemones, ranunculi, or other types "of an Alpine flora. The rocks were chiefly a very hard porphyry, red, black, and grey, with granite here and there, and beds of limestone, all hard and obnoxious to plants. Moreover, these steep upper cliffs of the Atlas are alternately roasted by a blazing sun, or parched by a Sahara sirocco, or swept by moist north-west Atlantic gales, which bring heavy snowstorms such as we experienced, probably throughout the year. The flora up to 7,000 feet, on the contrary, is exceedingly rich, varied, and beautiful;" and Dr. Hooker thinks that their collections will prove of very great interest and considerable extent. Many English plants find their southem limits here, and there is an abundance of roses, bramble, elcler, honeysuckle, ivy, ash, poplar, \&c.

A French physician, Dr, Brierre de Boismont, has discovered a new disease, a form of contagious mental alienation, from which, he states, the members of the Commune suffered during the late insurrection in Paris, and which he terms the morluns denocraticus.

We have received during the past week Les Mondes for March 23, and the Monitenur Scientifizue for May I and I5, together with the Comptes Renulus to May 29, we trust an earnest of the re-opening of the scientific intercourse with Paris which has for long been so lamentably interrupted.

WE learn that the celebrated collecition of Egyptian antiquities made by the late artist antiquary, Robert Hay, of Linplum, recently exhibited at the Crystal Palace, has been purchased by a well-known banker in Boston, U.S.A., and it is now being shipped for that city. We regret that so valuable a collection shlould be allowed to leave this country, and congratulate America on the acquisition of so important and in many instances unique an addition to its antiquities.

ON Saturday, June 10, the boys belonging to the Geology Class at Christ's Hospital went to some pits at Woolwich and Charlton, under the care of Professor Tennant. Unfortunately the rain detained them for an hour, but, notwithstanding the inconveniences caused by the wet, some interesting specimens were discovered, and a somewhat better idea of what geology really is was obtained from the practical work that they did.

IN a note in a recent number of the American Naturalist, Prof. Dawson repeats his assertion that his Prototaxites Logani of the Erian formation of Canada is a true exogenous tree, with bark, rings of growth, medullary rays, and well-developed, though peculiar woody tissue; and not, as Mr. Carruthers has maintained, a gigantic alga.

MR. F, G. SANBORN has been appointed instructor in Practical Entomology in the Bussey Agricultural Institution of Harvard University.

CONGRESS recently appropriated 40,000 dols. for the annual expenses of the U.S. Geologist, Dr. F. V. Hayden, who is surveying the Rocky Mountain region of Colorado.

PROF. HENRY, of the Smithsonian Institution, has received the decoration of "Commander of the Order of St. Olaf," from Charles, King of Sweden and Norway. joint resolution has been offered in Congress to enable the Professor to accept the honour.

DR. WILLS DE HASS is about to start on an extended visit of exploration in the Valley of the Mississippi, with a view of determining the character of certain ancient works in the vicinity of St. Louis.

At a meeting of the New York Lyceum, held on May 15, the president, Prof. Newberry, of Columbia College, gave a summary of what was being done in the line of geological exploration thronghout America - a task he was well qualified to perform, liom his intimate acquaintance with the subject, and from his own connection with one of the most important of these enter. prises. He congratulated the Lyceum upon the prospect that what he called the Chinese puzzle of New England geology is in a fair way to be worked out during the present season by means of the concurrent labours of several eminent geologists. Among these he mentioned Sir William Logan, late director of the Geological Survey of Canada ; Prof. C. H. Hitchcock, the State Geologist of Vermont ; and Profs. Shaler and Hyatt, of Eastern Massachusetts. Prof. Dana also proposes to carry a geological section from the valley of the Connecticut to that of the Hudson. The following additional items were mentioned in the communication of Prof. Newberry : the geological survey of Canada will be continued under the direction of Mr. A. R. C. Selwyn, who succeeded Sir William Logan in its chief direction.

We learn from Harper's Weekly that Prof. Winchell has resigned the directorship of the geological survey of Michigan; but the work will be carried on by the board of trustees, Major Brooks devoting himself to the iron region. Prof. Pumpelly declines to continue the survey of the copper district, and asks that the small appropriation may be turned over to Major Brooks. The current surveys of Indiana, Illinois, and Missouri are to be continued during the year, and a new survey has been authorised in Arkansas. No positive appointment of director for this work lias yet been made, although the place has been offered to Prof. Orton, of the Ohio geological corps, and declined by him. Bills providing for surveys of Pennsylvania and West Virginia were introduced into the Legisiatures of those States during the past winter, but failed to become laws.

A LABOKATORY for the use of students in practical inorganic chemistry having been opened last September at the Oldham School of Science and Art, twenty-two artisan students pre. sented themselves for-examination by the Department on the $4^{\text {th }}$ of May, and fourteen of them have passed.

\section{ON THE NECESSITY FOR A PERMANENT COMMISSION ON STATE SCIENTIFIC

$$
\text { QUESTIONS * }
$$

THE duty of the Government with respect to Science is one of the questions of the day. No question of equal importance has perhaps been more carelessly considered and more heedlessly postponed than this. And now that a hearing has been obtained for it, neither the governing class nor the masses are qualified to discuss it intelligently. The governing class, because it is for the most part composed of men in whose education, as even the highest education was conducted thirty to fifty years ago, science occupied an insignificant place; and the masses, because they may be taken to be virtually destitute of scientific knowledge. Those who wield, and those who confer, the powers of govern. ment being alike incapable of dealing with this question, it devolves on another section of the community to urge its claims to attention.

The section qualified to do this is composed of scientific men, properly so called, of professional men, such as engineers, and certain manufacturers who are engaged in applying science prac tically, and of a limited number of officers in the naval and military services. This section is without much political in. fluence, but its intellectual power is enormous, and this power has never been so strongly exerted, or so decidedly acknowledged, as at the present time.

A tangible acknowledgment of the claims of science consists in the recent appointment of a Royal Commission "on Scientific Instruction and the Advancement of Science," which is now sitting. The problem which this Commission is expected to solve is one of very great complexity, delicacy, and difficulty. It has to survey the whole world of scientific thought, and to construct a chart on which the districts that it is the duty of the State to occupy shall be clearly delineated, with boundary lines so drawn as not to trench upon tracts which may be best left to individual or corporate management. It has then to devise a form of government of which not a trace at present exists, fitted

* Abstract of a paper read at the Royal United Service Institution, by Lieut. -Colonel Strange, F.R.S. 
to administer the affairs of the newly-acquired territories. Instruction in science is one thing, and, I admit, an indispensable thing, without which there can be no foundation for future scientific progress; scientific investigation is another and perfectly distinct thing, constituting the end to which instruction is the means. Each may be pursued separately and solely. but if instruction be scanty, investigation will be unsound; if investigation is neglected, progress must be impossible. It will be for the Royal Commission now sitting to point out the relation of instruction to investigation, and to decide how far and by what agency the Government may beneficially aid each.

The first report of the Royal Commission has been published. It deals with certain limited matters of detail only, relating to the occupation of some new buildings at South Kensington. Possibly the settlement of these details may have claimed immediate attention with reference to the arrangement of the buildings in question. This first report has therefore not touched the great problems above adverted to, which await the deliberation of the Commission, and an authoritative solution of which at its hands is anxiously expected by the scientific world.

It may be asked why, as a Royal Commission is investigating the relation of Science to the State, the subject of the present paper should be brought forward independently of that body. The reply is, first, that discussions of any of the questions on which the Royal Commission is deliberating can hardly fail to afford light and assistance useful to the inquiry; secondly, that the problem submitted to the Royal Commission is, "How should the State aid Science?" whereas the question on which I am to address you is totally different, namely, "How can Science aid the State?" Although this latter question may be considered by the Royal Commission, it is certainly not necessarily a part of their programme, and as it is a question of at least equal importance with the former one, it is most undesirable that it should be overlooked.

To the question, "How can Science aid the State?" I reply, "By means of a permanent scientific commission or council, constituted for the purpose of advising the Government on all State scientific questions."

In order to apprehend the aim of this proposal, its practical operation and probable results, it must be examined systematically and in detail. I propose to do this under the following heads:-

I. The scope implied by the term State scientific questions, and the importance of those questions.

IX. How are such questions at present clealt with, and with what results?

III. What should be the constitution and functions of the proposed Council of Science?

IV. What objections can be alleged against the proposed council ? . . . .

[On the second point we quote the following :-]

II. How are such questions at present deali with, and with what results? - I wish to preface my remarks on this head by saying that they are not intended to apply to any particular party in politics. In speaking of the shortcomings of the Government, I mean to include ALL administrations, whatever political principles they may have represented. I cannot perceive any difference worth noting between different Cabinets as regards science. All have, in uny opinion, displayed, in the most elaborate manner, their incapacity to grasp science as a national matter. I am not aware of a single attempt on the part of any Government that has ever existed in England to define its duties with regard to science, or to model any administrative agency for dealing with it in a rational, efficient, and comprehensive manner. It would be invidious and unjust to single ont any set of Ministers as having been more negligent in this matter than others, where all have been to all intents and purposes equally indifferent to it.

How then are State scientific questions now dealt with ? The answer is, desultorily, capriciously, inefficiently, irresponsibly, when they are dealt with at all, but in many instances of the greatest moment they are absolutely neglected. The number of questions involving science on which Government has to decide, are innumerable and never ending. Every day adds to their number and their urgency. This vast increase of such questions has taken place within a period which, in the life of a nation, is very brief. . . . . Our official scientific arrangements are substantially the same now as they were in the pre-scientific era -they may be more extensive in degree, but they are the same in kind-the butter may be spread further, but there is not more butter. The enormous scientific activity of the last 30 or 40 years does not seem to have struck the official world as a fact having a bearing on the humdrum routine of the Departmentsmore secretaries-more clerks-more subordinates of various kinds have been appointed to prevent accumulation of arrears; more conmittees of inquiry have sat, more scientific witnesses have been examined, more reports published, if not read. But not a single step has been taken towards the creation of an organisation capable of concentrating and directing all this scat. tered effort.

The example of foreign nations, the pressure of the public, and the demands of inventors, daily set before the Government scientific puzzles, which they are often, if not generally, at their wits' end to solve. It never seems to occur to them that these puzzles will never cease, and that they will increase in difficulty as a matter of absolute certainty. The attempt is made to stave off by temporary expedients work of a permanent character. The puzzles are guessed at, and the guess is oftener wrong than right. Problems too deep for guessing are either pushed out of sight or submitted to methods of investigation that end in a blunder, perhaps a catastrophe.

I do not wish either to declaim or to exaggerate. I will briefly indicate the provision that cloes exist for the solution of State scientific questions. It is of three principal kinds. First, official subordinates in various clepartments. Second, temporary and special Committees. Third, consultation with individuals eminent in science, or with scientific bodies. I omit debates in Parliament, because no scientific question ever was or will be solved by such an assembly, and I omit also the press, which is so influential in other respects, as altogether unreliable for such inquiries.

The objections to the first kind of provision, viz., official subordinates, are, that such persons have almost invariably other duties of an executive nature to perform, and have not therefore the leisure necessary for scientific investigation. Science, moreover, is now in a stage in which scarcely any one problem can be adequately grasped by a single mind; this semarl particularly applies to State scientific problems, which are invariably of a nixed order, requiring a great variety of attainments for their perfect comprehension. I astly, subordinates are disqualified for the office of advisers by the very fact that they are subordinates. No inferior can be expected to urge distasteful counsels on a powerful superior, and no superior can be expected to abandon his own preconceived ideas in consequence of the timid and feeble remonstrances of an inferior under his orders. Subor. dinates then are unfitted to be counsellors, because they must in the majority of cases be deficient in leisure, attaimments, and independence.

One clear, decided example of the inadequacy of this source of scientific advice is as good as a thousand. [The loss of the Captain was then referred to.]

The second expedient-temporary Committees, has been very largely employed for the purpose of guiding the Government through their scientifie difficulties. There are very serious objections to this expedient. First, there seems to be no rule, either for their appointment or for their composition. If the Government is much pressed by public opinion (which on such subjects is not over-well informed), or if it sees a difficulty ahead, which, however, it often fails to do, a Committee is the result. But there is no guarantee for the proper composition of the Committee. There always lurks about some of the names a suspicion either of incompetence, or of leaning towards the supposed foregone conclusion of the Government. But, passing by such suspicions, there remains the fact, that the members are selected either by some Minister who, not being a scientific man, probably knows nothing about the qualifications necessary for conducting the proposed inquiry, or by some outside and irresponsible person to whom the Minister has applied for help. It is quite overlooked that the selection of the proper persons for conducting any given inquiry can only be made by some one having a knowledge of the subject of the inquiry, or of subjects cognate thereto; the selection is in itself a scientific question. Though some temporary Committees have done good service, it may be safely declared that on the whole they have failed to give reasonable satisfaction.

A second objection to such Committees consists in the fact itself that they are temporary. As such they necessarily commence their labours, however well they may have been selected, with but a partial and confused knowledge of the question at issue, and much time is lost in gaining some insight into it. After much work and expense, they reach a certain stage in the inquiry at which a report is possible. Perhaps by that time the 
public pressure, or other cause that led to their appointment, has died out, or action is necessary, -in either case the Committee is considered to have served its purpose, and is broken up; the members disperse, take up other duties, the knowledge of a particular subject which they gained in the course of their inquiry is lost to the country, and a scientific problem is left half solved, until at some future day it must be taken up again for completion, and the old work gone over de novo. The system of temporary Committees, in fact, implies a belief that finality is attainable in those mixed scientific problems in which chiefly the State is interested, or that such problems can advantageously be taken to bits and studied piecemeal ; whilst the fact is, that no one such problem that can be mentioned ever has, or ever will, as long as human ingenuity survives, come to an end. Permanent arrangements alone can deal with the unbroken continuity and unceasing change of scientific development.

A third objection to such Committees consists in the fact that much of the investigation carried on by several Committees may be common to each. This involves the repetition of the same work, and great consequent waste of time, effort, and money.

I come now to the third source from which the Government draws its scientific inspiration, namely, individuals eminent in science, and scientific bodjes. Recourse is had to such sources without any system whatever ; there exists no rule, for instance, defining what cases should be submitted to an individual, what cases to a scientific society, and what cases to a temporary Committce. Nor is it possible to assess the degree of responsibility attaching to an individual or to a scientific society advising the Govemment. If the advice so obtained is rejected, nothing about it is known publicly; if it is adopted and turns out unsound, the right to blame the adviser is absent. It is impossible to ascertain when such consultations have occurred, and with what results. The probability is that they are not frequent. During the two years that I served on the Council of the Royal Society, I only remember one application from Government for advice. It was on some point connected with coppering ships. A committee was formed of the most competent persons, and probably very sound counsel was afforded. But it is evident that this is an expedient that camnot be frequently employed, as it would occupy too much of the time of the Society, which should be devoted to its legitimate objects. Advising the Government is certainly not one of these, nor should the Government of a great, powerful, and opulent nation like England be reduced to such makeshifts as private societies for direction in matters of such tremendous national moment.

Having shown, I trust, that Government is without recognised scientific advisers, I proceed to discuss :

III. What should be the constitution and functions of the proposed Councit of Scimce? - The ground requires to be cleared before approaching this question. I have heard it urged that the various departments of the State should be complete in themselves, each with its own consultative element, as distinct from its executive. This appears at first sight a plausible arrangement, but it will not bear examination. Many of the scientific inquiries that devolve on the Government affect several departments, and in such cases it would be wasteful to have numerous repetitions of the same investigation when one would do; and if, under the supposed arrangement, one investigation of a given class of subjects was decided on, the selection of the particular department to which it shonld be referred would cause endless bickerings and jealousies, - the co-operation of departments being, like universal peace, a somewhat remote hope. Again several departments would require identical scientific adviser's.

For these reasons I discard this suggestion, and revert to the proposal which forms the subject of this paper, namely, that there should be one permanent great council for advising and assisting the Government on all State scientific questions. This council should be purely consultative, not executive. All departments should equally be entitled to its assistance. The Council should not be expected to initiate questions, though it might occasionally see fit to propose certain investigations to the Government, without whose sanction, however, they should not be undertaken. The Government should not be bound on all occasions of scientific difficulty, either to resort to, or be guided by, the opinion of the Council ; but it would of course become in either case absolutely responsible for all consequences. .

The duties that would devolve on this Council, stated broadly, would be-

Ist. To advise the Government on all questions arising in the ordinary routine of administration, submitted to it by the various departments.

2nd. To advise the Government on special questions, such as the founding of new scientific institutions, and the modification or abolition of old ones; the sanctioning of scientific expeclitions, and applications for grants for scientific purposes.

3 rd. To receive, consider, and decicle upon inventions ten dered to Government for the use of the State.

4th. To conduct or superintend the experiments necessary to enable it to perform the above duties.

As to the first branch of its duties little need be said. The number and variety of questions involving scientific considerations entering into the current work of the different departments are almost unlimited. A large proportion of them could be answered at once by competent persons, but there would remain many that require investigation, discussion, and often experiment.

The second branch, special questions, would not perhaps be so extensive, but it would be exceedingly important. At present there exists literally no provision for dealing with such questions. Sometimes one person, supposed to have a knowledge of the matter at issue, sometimes another is consulted, sometimes no one. At present the Royal Commission now sitting is probably dealing with the subject of existing and required scientific institutions. But supposing this body settles all such matters in the most satisfactory manner at the present time, a reconsicleration of them will very soon be demanded by the rapid advance of science, and the perpetually changing relations of different lines and modes of physical inquiry. But the Royal Commission is a temporary body. Its functions will sooner or later cease, whilst the mutarions and permutations of scientific thought are incessant. Questions relating to State scientific institutions require ceaseless watching,--never-ending modification. A permanent body, such as I propose, alone can preserve the national scientific establishments in a condition of vigorous efficiency on a level with the existing state of physical knowledge.

The sanctioning of special scientific researches and expeditions will be a very important duty, which there is at present no one qualified to perform.

Sanctioning of grants of money for aiding scientific objects comes under the same head as sanctioning expeditions. A present $f_{1}, 000$ per annum is granted by Government for such purposes, and it is distributed by the Government Grant Commitcee of the Royal Society. As a member of this committee I can testify to the extreme care, fidelity, and impartiality with which it performs this gratuitous duty, The amount of the grant might with advantage be much increased, as at present only small sums can be given out of it to each applicant ; these are often quite insufficient, and as they must unavoidably be small, no application for aiding extensive and costly researches can expect efficient aid from so narrow a source. The proposed council would be a public body, precisely qualified to perform the duty now imposed on private individuals.

The third branch of duties devolving naturally on the council would be the dealing with inventions tending for the use of the State.

The fourth class of cluties which the Council would have to perform would relate to the experiments and investigations necessary to enable it to perform the duties previously enumerated. Regarding the necessity for providing the Council with the agency, appliances, accommodation, and funds requisite for these purposes, there can hardly be two opinions. They are absolutely indispensable.' I need not here attempt to define what would be wanted. Such details would follow naturally the affirmation of the great principle involved in the creation of the Council.

I come now to a question on which opinions may differ-. namely, the question whether the Council should be a paid or an unpaid body. I say, unhesitatingly, that it should be handsomely paid. If the heads of duties to be performed, of which I have given but an outline, be duly considered, it will be seen that they will be laborious, responsible, and beneficial in the highest degree; and that they can only be adequately performed by highly qualified persons. It is idle to expect that such men as will be necessary, will devote themselves almost exclusively, as they will have to do, to such labour from pure love of science and of their fellow-creatures. The delights of philosoplical speculation are one thing, carrying with them their own reward - a reward beyond any money consideration; downright official routine work is quite another thing. In no other professional 
freld is it unpaid; nor is it ever worth much if not paid for. It has hitherto been too much the custom to treat men of science as exceptions to all other professions; to assume that whilst it is quite proper to enrich and emoble soldiers who fight for pay, lawyers who evade or apply the law according to circumstances; physicians who kill or cure as seemeth best to them; and even divines, whose mission to save souls might be deemed a sufficient privilege: the man of science who contrives the arms with which the soldier wins his fortune and his coronet, who surrounds the lawyer, the physician, and the divine with the luxuries which their superior privileges enable them to command, should work for love, and die, as he too often does, in poverty.

If the Council, the creation of which I now advocate, does its duty, it will confer benefits untold on every member of the community, from highest to lowest ; from the military and naval appliances necessary to protect our unequalled national wealth, down to the smallest and least regarded necessaries of our ordinary life, the influence of this Council will be felt ; and is it either just or wise to expect such benefits for nothing?

[The author then gives some indication of the mode of constituting the Council.]

IV. What objections can be alleged against the proposed Council? -Difficulties innumerable can of course be conjured up in this as in every case of reform, but I have only heard three definite objections raised that seem to me to deserve any notice. They are :-

Ist. That this is a system of centralisation, and therefore objectionable.

2nd. That it will be liable to jobbery.

$3 x d$. That it will be too costly.

I will touch on each of these briefly.

As to centralisation, I admit the impeachment, but claim it as an advantage, not an evil. Those who are scared by centralisation forget that it constitutes the very basis of civilisation and of stable efficient government. In primitive savage life there is no centraIisation, no united effort for a common purpose. Each individual struggles single-handed for his rights. Civilisation teaches us to set apart certain members of the community for purposes beneficial to the whole, to form them into distinct bodies, having definite duties to be executed, under the direction of a head central authority. The army, the navy, the police, the postoffice, are examples of such bodies, the animating and ruling law of which is centralisation. In the case of the police, we have local, in the other cases imperial, centralisation. The body we are considering will have to perform duties of a strictly imperial character, contributing directly to the efficiency of the defensive power of the empire, and to the security and well-being of every member of the community. It is a body which not only would not be effective, but which could not exist but in a centralised form.

As to the second objection, that the arrangement I have proposed would be liable to jobbery, I must own that, as I contemplate the employment of human beings only, I do certainly expect to see the operation of human motives. But if jobbery be a fatal objection to the scheme, then on the same principle we ought to have no army, navy, church, bench, magistracy, municipalities, or Parliament, for in each of these the discovery of some traces of jobbery will probably reward a diligent scrutiny. It is not apparent why a degree of purity not dreamt of in regard to any other profession should be insisted on when science is in ques. tion; nor is it clear why men of science should, a priori, be deemed more corrupt than their neighbours. Of course every precaution should be taken against corruption in so important a body, and the rest must be left to that sense of honour to be found in all other professions, and of which even men of science are perhaps not entirely devoid.

The third objection, undue costliness, is, in my opinion, as invalid as the other two. My proposal has two main objectsto increase efficiency, and to diminish blunders. Both are in the strictest sense economical objects. If it does not seem calculated to attain these objects, it should on no account be adopted. If it gives satisfactory promise of their attainment, no expenditure that it is likely to occasion will be too great in order to secure them. Let any one who is terrified by the cost, visit our ports, dockyards, and arsenals, and there see the ships that have been built which should not have been built, the cannons made that should never have existed, and the useless arms and equipments of the pre-scientific ages. Let him count the cost of these, and compare it with the probable cost of substituting for the reign of haphazard ignorance a reign of systematic intelligence. To take one example-that of Her Majesty's ship
Captain. This vessel, with her armament and stores, probably cost the nation three or four hundred thousand pounds. Who shall assess in money the value of the 500 noble lives that perished with her? Would not the nation willingly give a million to have them back? If so, we have as the cost of one single blunder committed by one Department something like a million and a half of money, a sum that would go a long way to permanently endow a body which, had it existed a year ago, must have prevented that blunder. But if $I$ dwelt on the preservation, prolongation, and increased comfort of civil life which such a Council would tend materially to secure, the cost of its maintenance would appear absolutely insignificant in comparison with the blessings it would shower on the nation. Against the cry of costliness I oppose the assertion, easily established, that nothing is so ruinous as disregard of the laws of nature, and nothing so profitable as intelligent obedience to them. Science, looked at in the dryest commercial spirit, must, in the long run, pay.

I must guard myself against the supposition that the proposal I have here advocated comprises all that is necessary for the efficient administration of scientific State affairs. It is only one part of a great system that has to be created. Other parts of the system will, no doubt, receive due attention from the Royal Commission now considering them. But there is one part so important that I feel called on to name it ; I mean the appointment of a Minister of Science. He need not necessarily be exclusively devoted to science; he might, perhaps, with advantage, have charge of education and the fine arts also ; but some one in Parliament clirectly representing the scientific branches of the national services has become absolutely indispensable.

When we have all Scientific National Institutions under one Minister of State, advised by a permanent, independent, and highly qualified consultative body--when we have a similar body to advise the Ministers of War and Marine in strategical science -then the fact that, in accordance with our marvellous constitution, these Ministers must almost necessarily be men without pretension to a knowledge of the affairs which they administer, need cause us no alarm. When these combinations have been, as they assuredly will be, sooner or Iater, effected, the wealth, resources, and intelligence of the nation, having due scope, will render us unapproachable in the arts of peace, and unconquerable in war-but not till then.

In conclusion, I must clain for the proposal I have advocated that there is nothing revolutionary in its character.

I aim at creating no new principle. We have already, as an integral part of our administration, a body constituted on the very same principle as that ncw advocated. I allude to the Council of India.

My proposal, therefore, I maintain aims at the creation of no new principle,-but only at the extension of one already existing, and universally approved after long experience. Nor do I aim at creating new labours. The work of which $I$ have been speaking is now being done, or suppposed to be done, and it is paid for heavily by the nation, but it is not well done. I propose to improve its quality by improving the agency to which it is assigned. I propose to substitute concentration for scattered effort, system for chance, organisation for disorder. I propose neither to exact from the Queen's advisers new duties, nor to fix upon them new responsibilities. The end and aim of my proposal is to lighten their labours and anxieties by putting into their hands better arms than those with which they now vainly strive to uphold the power and glory of the nation.

\section{A. STRANGE}

\section{SCIENTIFIC SERIALS}

THE last part of the Sitzungsberichte of the Isis Natural History Society of Dresden contains the proceedings of the Society for the months of July, August, and September, 1870 . In the section of Prehistoric Archæology, Dr. Mehwald described kitchenmiddens on Zealand and Jutland, and on the Andaman Islands, and stated that M. Lorange of Fredrikshald, in'Norway, has investigated a grave in that neighbourhood which he believes to have been a family grave, in which the bodies were deposited one above the other, the one first buried being probably at a depth of 600 to 700 feet.-Prof. Geinitz explained Delesse's Geological Map of the Department of the Seine, and remarked upon the occurrence in that district of the bones of extinct animals associated with artificial products and the remains of man. He also 